\title{
The gene patenting controversy
}

\author{
Jeremy Sklarzyk, Emma Jameson, Nasteha Abdul- \\ lahi and Mahnoor Shah
}

\section{Abstract}

Genes are found in every living thing. They make us who we are. In the modern age of rapid technological advances, it is common for new discoveries to be patented for profit. A question arises. Does finding and isolating a human gene make it patentable by a company? This question has spurred much controversy over the last few years. Last year, a medical company called Myriad Genetics tried to patent the human gene that is responsible for breast cancer. To further understand the opinions of the public with regards to the issue of gene patenting, we conducted a study in one high school in Mississauga. Our results showed that the majority of teenagers are against gene patenting. However, we learned that teens knew very little about this issue. This motivated us to take action by making two informational videos on gene patenting to spread awareness among our peers and the wider community. In addition, we reached out to a group called Breast Cancer Association (BCA) by writing a letter to express our solidarity. We received a 'thank you' reply for BCA shortly after the U.S. Supreme Court ruled against gene patenting. 


\section{Introduction}

In the 1990s, Myriad Genetics patented the BRCA1 and BRCA2 genes (De Vouge, 2013). BRCA genes are linked to breast, ovarian, and many other types of cancers. In general, women have a $12 \%$ chance of developing breast cancer at some time in their lives; however, women who carry the mutated BRCA1 and/or BRCA2 genes have about a $60 \%$ chance of developing cancer (Fisher, 2013). In other words, women carrying this mutation will be about five times more likely to develop breast cancer.

Having patents on the BRCA1 and BRCA2 genes gives Myriad the ability to enhance methods of isolating and studying the genes. Accordingly, scientists and companies that have devoted their time to studying the BRCA genes will have to focus their attention onto new research as they are currently and legally not allowed to conduct studies on the BRCA genes (De Vouge, 2013).

Gene patenting harms the credibility and wellbeing of society. One of the main issues with gene patenting is whether or not the patent itself is valid; a gene is a discovery, not an invention (Franco, n.d.). Myriad claims they only have patents on the man-made isolated copies

\section{Our Study}

On June 3, 2013 we conducted a study including 60 students from Erindale Secondary School concerning the gene patenting issue. The main purpose of this study was to determine whether or not there was a correlation between gender and levels of awareness on the issue of gene patenting. In order to accurately determine if there was a correlation, an equal number of males and females participated in our study. The study was conducted to learn of the BRCA genes, making them patentable because they are not naturally occurring. The synthetic copies of the genes are indeed 'copies,' making them no different from the natural genes. Therefore, our opinion is that the gene is not patentable because Myriad Genetics did not create the gene as it already existed. In relation to this, Myriad argues that they determined the process of isolating the gene and the technology to create copies of the gene. Myriad should patent the technology for isolating genes and not the genes themselves (Huffington Post Live, 2013).

Another big issue in the gene patenting controversy is the pricing of the testing of the BRCA genes conducted by Myriad Genetics. The patent has a big impact on society as people are legally not allowed to be tested for the BRCA genes by anyone other than Myriad Genetics or companies that have purchased rights from Myriad to test for the genes. Many individuals may not be able to afford this test as it costs $\$ 3,340$ (De Vogue, 2013). This means that only rich in our society could afford to be tested, and this is not fair to the rest of the population.

how a group of teenagers viewed the controversial issue of gene patenting. The format of the study was a survey, which included a series of statements and questions asking teens about their opinion on the issue. The participants first circled whether they are male or female and then read the statements and questions to circle the answer that they felt was correct depending on their knowledge and/or opinion. We analyzed and interpreted the results. 


\section{Data Analysis and Interpretation}

The graph in Figure 1 shows that there is no correlation between gender and one's opinion regarding Angelina Jolie's preventative surgery. $80 \%$ of females and $73 \%$ males agreed with Angelina Jolie's decision. There is only a slight difference $(7 \%)$ between the genders meaning that both genders have relatively the same opinion. A possible reason for the small difference, however, may be connections that females have towards Angelina Jolie and understand the circumstances and risks of breast cancer more than boys. However, males with breast cancer and males carrying the BRCA gene mutations are becoming more prevalent in society (Adams, 2013). Both genders support Jolie's decision probably because they both think that preventative surgery will save her life. Not getting the surgery may be worse for her.

The graph in Figure 2 shows some correlation between gender and one's opinion on the subject of gene ownership by companies. $43 \%$ of females think that companies can own human genes through patents while only $26 \%$ of males think the same. According to Myriad, they do not own the natural gene but instead the man-made copy that they make. The two are completely identical, but they are not "extracting" the gene directly from a person. This may be what some girls are thinking and why more agree that companies can patent a part of the human genome. Sources argue that it does not matter how the gene is found, it is still not an invention ("Why are gene,"2013). This may well be the opinion shared by more boys who disagreed with corporations patenting genes.

Lastly, graph in Figure 3 depicts no correlation between gender and one's opinion about profit generated by Myriad from BRCA gene testing. $80 \%$ of teenage girls surveyed believed that it is wrong that Myriad is the only company offering and profiting from testing while $73 \%$ of boys thought the same. The other $20 \%$ of girls and $27 \%$ of boys may agree with the opinion that Myriad spent $\$ 500$ million dollars in research for this and therefore they deserve the profit ("Patents save lives, air innovation," 2013). This data allows us to make the assumption that for this particular question, there is no gender correlation.

Based on our study we feel that our peers still need more education about this issue. Although teenagers have opinions, we still need more education about this issue. We decided to raise awareness about the issue of gene patenting through several actions that are discussed next.
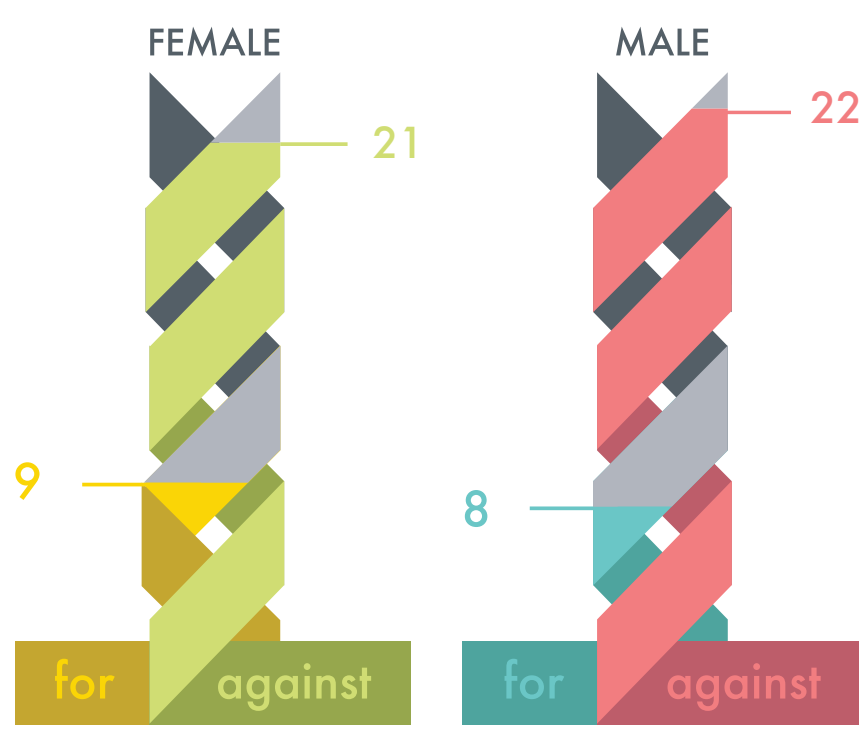

Figure 1: Results showing the number of female and male students who agreed and disagreed with Angelina Jolie's decision to undergo preventative surgery based on the results of the BRCA gene testing.
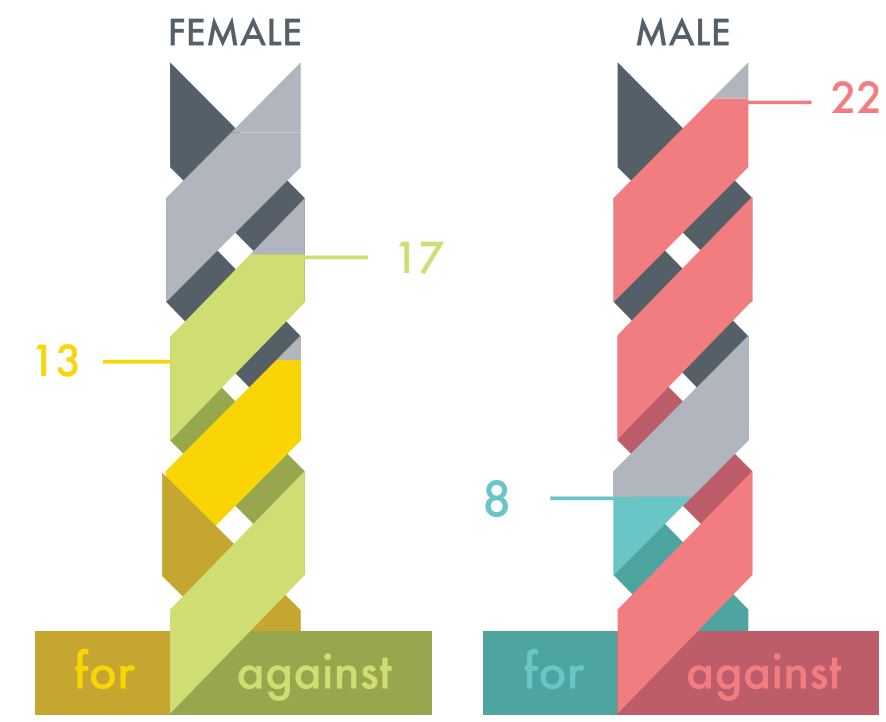

Figure 2: Females and males opinion on whether companies can own a human gene 


\section{Taking Action!}

We produced two informational videos. The first video shows individuals being interviewed around the school (https://www.youtube.com/watch?v=I-FAEAzWKEs). We asked similar questions as in the study. The same individuals were given a document showing both pros and cons of the issue and were asked the same questions again. This was done to see whether or not more information on the topic would change the minds of our subjects from their previous statements. It also acted as means of raising awareness and educating our peers. This in itself is worth studying further - if the opinions of our peers changed after learning more about the issue.

The second informational video explains what gene patenting is by going further into the Angelina Jolie case and explaining that she had to pay a large sum of money to Myriad in order to get her BRCA1 and BRCA2 tests done (https://www.youtube.com/watch?v=dLGpRxZ3Rho).

We also decided to write a letter to Breast Cancer Association (BCA) who opposed gene patenting. We wanted to show our solidarity with BCA. We received a reply from them, which came shortly after the U.S. Supreme court ruled against gene patenting. We felt proud that $\mathrm{BCA}$ recognized our learning and involvement in this critical socio-scientific issue.
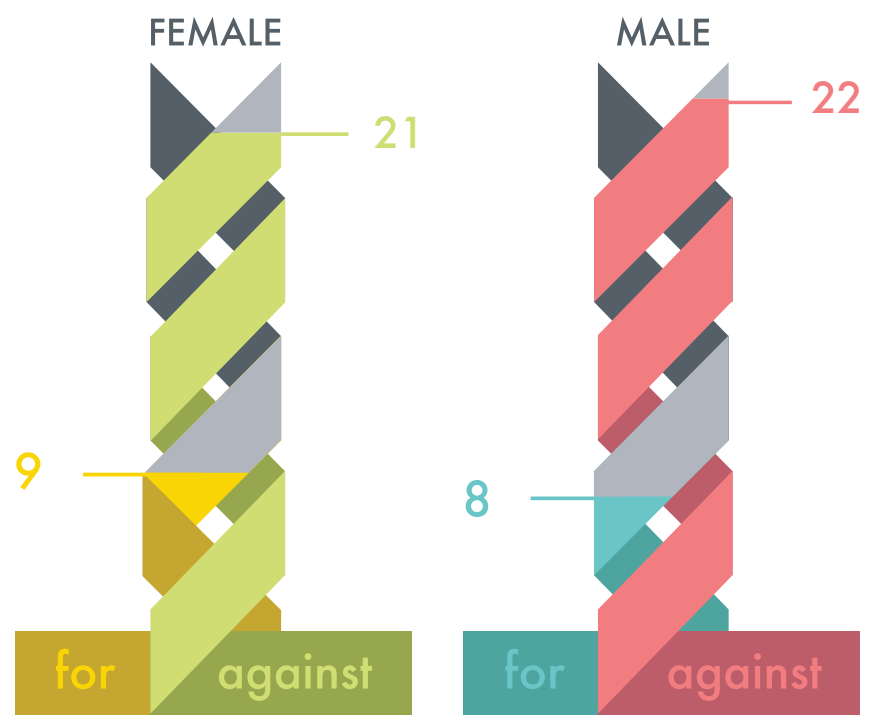

Figure 3: Female's and males' opinion on whether it is right or wrong for Myriad to profit from BRCA gene testing 
In the 1990s, a company called Myriad genetics got patents for the BRCA 1 and BRCA 2 genes and diagnostic procedures. Patients who have mutations in these genes are at a very high risk of developing ovarian and breast cancer compared to people that don't have the mutation. Myriad Genetics checks if a person has mutations of these genes and if so that person should undergo a surgery to lessen their chances of developing breast and ovarian cancer.

\section{Points For and Against Patent}

For Patent

- Myriad is not patenting genes "as they occur in nature," nor do they own something that is a part of you. They can't do that. However, according to current gene patenting laws, they CAN patent isolated DNA and cDNA (complimentary DNA)which they make in the laboratory, not take from the body. In simpler terms, they create a man-made copy of the gene and do not just take the gene out from a person.

- Myriad spent \$500 Million in Research over 17 years to discover these genes. To pay off that research, they must make that amount through testing for the gene. This may not be possible without the patent. Also, with the profit they make, they can fund more research for these genes to better understand them and the origins of these gene related cancers. This is also why testing is so expensive.

- Because money and recognition fuel the medical industry, gene patenting puts pressure on companies to make new medical discoveries faster. This will further change and make our medical treatments and understandings much better in a shorter period of time. Without gene patenting, companies may feel less motivated as it could mean less money and recognition. THis would slow down medical discoveries.
Against Patent

- Myriad makes actual copies of the BRCA1 and 2 genes which are identical to the ones naturally occuring in the body. Anyone who has the gene in their body can't check, test or examine the gene unless they pay to Myriad. If they are patenting man-made copies of the gene then why do patients have to pay Myriad to see their 'naturally occuring genes?' The patent should only be on the man-made copies not the naturally occuring genes.

- Myriad claims they can patent the genes because of isolation. Separating something that is entirely a copy of NATURAL GENES doesn't transform it into something 'new.' Only new inventions, products or methods can be patented. Myriad made a discovery, they did not invent something.

- Myriad already has a valid patent on diagnostic and isolation methods. These are most definitely patenable. Myriad can make money of of these patents to pay off their research and fund new projects.

- Prevents any other companies from testing and researching (meaning no one can get a second opinion) on the gene without paying money to Myriad. This stops life altering research that could save others.

Figure 4: Informational chart shown to peers to educate them more about the two sides of the issue before reassessing their opinions. 


\section{Reply E-mail from BCA}

From: Zoe Christopher<zchristopher@bcaction.org>

To: Mahnoor Shah

Sent: Monday, June 24, 2013 2:50:09 PM

Subject: RE: Gene Patenting

Dear Mahnoor, Jeremy, Nasteha, and Emma,

Thank you so very much for taking the time to write your very thoughtful letter about gene patents to Breast Cancer Action! As you know, shortly after you sent your letter the U.S. Supreme Court ruled in our favor and conclusively said human genes cannot be patented! This is truly a victory for all.

We applaud your involvement and work on this topic. I hope you let us know when your video is ready for viewing as we would be most interested in seeing it.

Thank you again for contacting BCAction!! Keep up your good work.

All the best,

Joyce (for Zoe)

Zoe Christopher, M.A.

Resource Liaison

Breast Cancer Action

\section{References}

Adams, M. (2013, May 20). Surgeons now cutting out healthy prostate glands of men who carrybrca gene. Retrieved from http://www.infowars.com/angelina-jolie-copied-bymensurgeons-now-cutting-out-healthy-prostate-glands-of-men-who-carry-brca-gene/

Common myths and facts about gene patents. Retrieved from Myriad website: http://www.myriad.com/common-myths-about-gene-patents/

De Vouge, A.V (2013, April 15). Can you patent human genes?. abc News, Retrieved from http://abcnews.go.com/Politics/patent-human-genes/story?id=18942966

Fisher, D. F. (2013, April 22). The curious case of human gene patents. Forbes, Retrieved from http:// www.forbes.com/sites/danielfisher/2013/05/22/the-curious-case-of-human-genepatents/

Franco, M. (n.d.). How gene patents work. Retrieved from http://science.howstuffworks.com/life/genetic/gene-patent2.htm

Huffington Post Live. (2014). Should anyone be allowed to patent human genes? [Web]. Retrieved from http://live.huffingtonpost.com/r/segment/should-anyone-be/5168113b02a76018b70004fb

Patents save lives, aid innovation. (2013, April 14). USA Today, Retrieved from http://www.usatoday.com/story/opinion/2013/04/14/myriadgenetics-supreme-court-editorialsdebates/2082553/

Risk of breast and prostate cancer in men with mutations in brca1 or brca2. (n.d.). Retrieved from http://brcascoop.com/brca1-brca2-info/cancer-risk/breast-cancerprostate-cancerrisk-men-with-mutations-brca1-brca2/

Why are gene patents controversial?. (2013, April 15).The Economist, Retrieved from http://www.economist.com/blogs/economist-explains/2013/04/ economist-explains-why-genepatents-controversial 